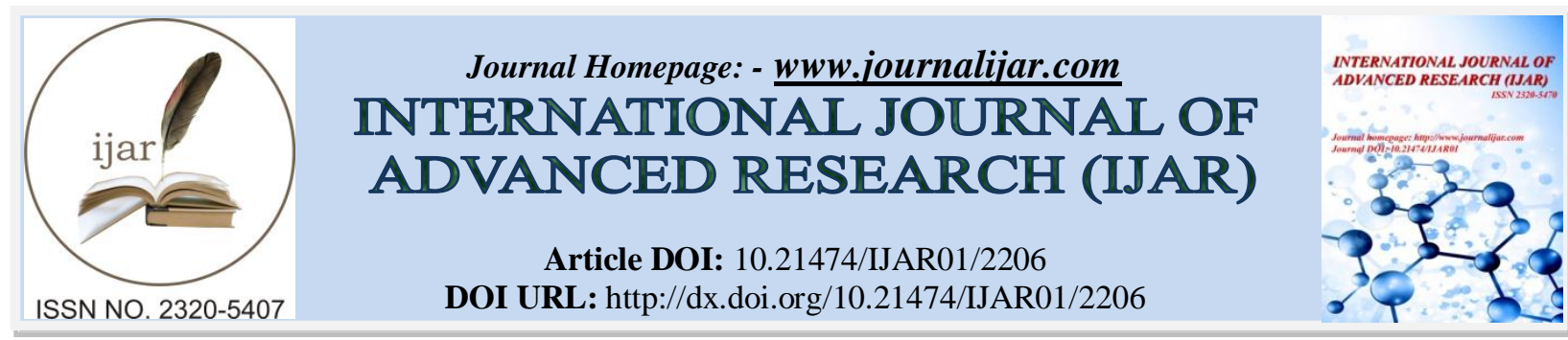

RESEARCH ARTICLE

\title{
MALE PARTNER INVOLVEMENT ON MATERNAL CARE SERVICES DURING PERINATAL PERIOD IN MUMIAS EAST AND WEST SUB COUNTIES, KAKAMEGA COUNTY, KENYA.
}

Sally Jepkosgei Kiptoo ${ }^{1}$, ${ }^{\text {Charles Mutai }}{ }^{2}$ and Mary Kipmerewo ${ }^{1}$

1. School of Nursing and Midwifery, Masinde Muliro University of Science and Technology, Kenya.

2. School of Public Health, Biomedical Sciences \& Technology, Masinde Muliro University of Science and Technology, Kenya.

\section{Manuscript Info}

\section{Manuscript History}

Received: 28 September 2016

Final Accepted: 30 October 2016

Published: November 2016

\section{Abstract}

Background: Globally male involvement on maternal health services remains a challenge to effective health care. Maternal deaths arise from pregnancy, childbirth and postnatal complications and this can be reduced by involving men. Benefits of male involvement have been acknowledged in developed countries, however there still continues to be a challenge in creating a space for and engaging men in maternal health. In Kenya male involvement in maternity care is one of the strategies for improving the maternal health and reducing maternal mortalities.

Objective: This study explored socio demographic, cultural and health facility factors associated with male partner involvement on maternal care services during perinatal period in Mumias East and West sub counties, Kakamega County, Kenya.

Methods: The data was collected using a pre tested structured questionnaire administered to 422 respondents (husband and wife). Four focus group discussions were conducted in groups of nine. Descriptive statistics was used to analyze socio demographic characteristics and inferential statistics using Kappa test, chi-square, odd ratio and Regression analysis using Statistical Package for Social Sciences (SPSS) version 21. Null hypothesis was tested at 5\% significance level. The study revealed that women initiated to seek antenatal care, but men eventually decide. Decision making power of men was grounded on education $(\mathrm{p}=0.001, \mathrm{OR} 2.030)$, occupation $(\mathrm{P}=$ $0,001, \mathrm{OR}=2.103)$ and living together $(O R=1.989)$. Social cultural factors of husbands also had influence on male partner involvement. Kappa test was 0.9945 implying agreement between husband and wife responses. Regression analysis, at 5\% significance level predicted that male participated by providing support $(p=0.001)$. Space $(p=0.001)$ at the health facility had negative influence on whether the man stayed with wife during labour.

Conclusion: Improving the levels of education and income of male partners, addressing cultural beliefs and practices, and sensitizing men on complications associated with pregnancy and child birth can contribute significantly in enhancing male partner involvement in 
maternity care. However, there remain a number of maternal health care service challenges such as space and privacy that need to be addressed before maternal health care become more male friendly.

Copy Right, IJAR, 2016,. All rights reserved.

\section{Background:-}

The issue of maternal health has predominantly been seen and treated as a purely feminine matter over the years. Globally the burden of maternal health is one maternal death per minute and from this, developing countries accounts for $99 \%$ of maternal deaths while male in developing countries are chief decision makers and therefore influencing maternal health outcome (Story, 2012). The International Conference on Population and Development in Cairo, 1994 and the Fourth World Conference on Women, Beijing pointed towards the need for involving and encouraging men to take responsibility for their sexual and reproductive behavior, advocating that men are in a position to change attitudes and practice through their positions as community, religious and political leaders (USAID,2010).

In sub- Saharan Africa the area of pregnancy and childbirth is recognized as the responsibility of women (Lochting, 2010). Before the onset of male involvement concern, reproductive health issues and services had become synonymous with women's reproductive health, and male were assumed to have no special role in such matters (Kakaire et al., 2011). But other studies done have reported positive benefits of male involvement in developed and developing countries which include: access to antenatal and postnatal services. Male who was part of ante natal and postnatal care partake in the education given at this clinics. This increases male's knowledge and participation and are able to identify danger signs hence facilitate women's utilization of maternity services (Tweheyo et al., 2010; Backstrom et al., 2009). Additionally, it also results in the reduction in delay in decision making while seeking emergency care. On the other hand, women who do not have company during labour and childbirth are five times more likely to deliver via caesarean section $(\mathrm{C} / \mathrm{S})$, longer duration of active phase of labour and higher pain score (Morshaso et al., 2009).

Indeed the women in labor have need for companionship, empathy and help. Women's childbirth experience have suggested four dimensions of the support that women want during labor namely; emotional support, informational support, physical support and advocacy (Plantin et al., 2011; D'Aliesio et al., 2009; MIDIRS, 2008). Attempts to encourage male to attend ANC and childbirth have been promoted by individual health facilities in Kenya, with mixed successes and failures similar to reports from other resource poor settings which indicated low male partner involvement (Kululanga et al., 2011). Attempts to involve male in maternal health care especially antenatal care, have managed to attract only few husbands due to African traditions (Aarnio et al., 2009).

In Kenya, few studies have been done to determine male involvement in reproductive health and figures are not available on the male partners who accompanied their wives both for ANC and delivery (Kwambai et al., 2013). In Western Kenya (Kakamega County), males are considered not to accompany their wives to maternity care services, a fact attributed to gender norms as one who accompanies the wife is branded as being overpowered by the wife (Onyango et al., 2010). Kakamega County is among the twelve counties in Kenya that has $4^{\text {th }}$ ANC attendance less than $50 \%$ (KDHS, 2014). Mumias East and West sub counties in Kakamega County contributes to this low percentage (KDHS, 2014). This study, therefore, aims to assess male partner involvement on maternal care services during perinatal period in Mumias East and West sub-counties, Kakamega County, Kenya.

\section{Methods:-}

\section{Study area:-}

The study was based in Mumias East and Mumias West sub counties located in Kakamega County in the western part of Kenya. Mumias East covers a surface area of $134.6 \mathrm{Km}^{2}$ with a total population of 117,294 people. While Mumias west covers a surface area of $191.8 \mathrm{Km}^{2}$ and a population of 129,965 (KNBS, 2009; Census 2009). The sub-counties have a population density of 515 people per square kilometer. Maternal health care services in Mumias are delivered through a network of health facilities both government institutions (GOK) and Faith Based Organizations (FBO), some of which were owned by Non-Governmental organization and the others were government facilities. The Abawanga community in Mumias has twenty one sub clans. There are two main religions in the area mainly Christianity and approximately 20\% Muslims. The Aba Wanga kingdom was visited 
by Arab and Swahili slave traders during the reign of Nabongo Mumia and this brought about Islam religion in the Wanga community compared to other Luhyas in Kakamega County.

\section{Study design:-}

The study used both quantitative and qualitative approaches.

\section{Study population:-}

The study investigated male partner involvement during pregnancy, labor and delivery and postnatal period in Mumias East and Mumias West sub counties, Kakamega County. The study population comprised of couples (man and wife) of 18 years of age and above in the study area, who were married and had a child in the last one year $(\leq 1$ year) preceding the study. The inclusion criteria was that one must has been married and had a younger child of one year or below, a permanent residence and from Abawanga Luhya community and must have signed consent to participate .

\section{Sampling procedure:-}

Kakamega county has 12 sub counties which were initially in 6 zones for administrative supervision and one zone was made up of two sub counties. One Zone was selected for the study by simple random sampling. Mumias East and West sub counties has seven administrative wards with a total of 15 locations and 30 sub locations. Simple random sampling was used to select $8(50 \%)$ locations and $15(50 \%)$ sub-locations. The subjects were identified through households. The household were systematically selected from one household to the other as long as subjects who meet the criteria were interviewed untill the number of required samples of 424 participants were attained.

\section{Data collection:-}

The data was collected using structured questionnaires and focused group discussion. All the participants who consented were issued with pretested self-administered questionnaire. The questionnaires were serialized starting with one (1) and a household was assigned to one serial number. Both questionnaires for the Male and the spouse were stabled together with the male questionnaire on top, a total of 424 questionnaires. Male respondents were a total of $212(100 \%)$ questionnaires administered and $212(100 \%)$ administered to women. Return rate was 422 (99.5\%) which were completely filled. According to Kothari (1993) over 60\% returns rate was acceptable return for a study such as this one. All data collected was stored. The hard copies were kept under key and lock while the electronic data stored both in the flash disk and computer secured with a password only known by the principle investigator.

\section{Data Analysis}

The quantitative data from the questionnaires was coded and entered into a computer for computation of descriptive statistics. The Statistical package for social sciences (SPSS) was used to run descriptive statistics to produce frequency distribution, and percentages. Inferential statistics such as chi square, Kappa test,odds Ratio, linear regression and binary logistic regression was used to determine associations between variables, its significance and prediction. Raw data collected was analyzed by assigning numerical values to each response and entering into a code book. Thereafter the numerical numbers representing responses from the questionnaires was transferred to a code sheet so as to obtain quantitative results from the closed-ended questionnaires. The researcher also formulated categories of responses for all open-ended questionnaires and FGD so as to obtain quantitative data. Chi-square linear regression and binary logistic regression was used to analyze quantitative data. Kappa test of association was used to determine whether there was association between the male's respond and the female respond. All p-values was considered statistically significant when was less than or equal to $0.05(\leq 0.5)$ Results were summarized, interpreted, reported and presented using percentages, frequency tables, and narrative description of the tables.

\section{Ethical considerations:-}

This study was approved by the Ethical Research Committee (ERC) of Masinde Muliro University of Science and Technology and permit granted from National Commission for Science, Technology and Innovation (NACOSTI). 


\section{Results:-}

A total of 424 respondents consented and participated in the study. From this, 212 were men respondents and 212 women respondents. Most of the male respondents (41.7\%) were between the ages of 25-29 years while (41.7\%) of the female respondents were between $20-24$ years old. On the hand, $3.8 \%$ of the male and $4.3 \%$ of the female respondents marry between the ages of 15-19 years. Majority (89.1\%) of the male respondents when grouped into two were between the ages of 15-34 years while minority (10.9\%) were between the ages of 35-49 years. The majority $(92.0 \%)$ of the female respondents were between the ages of 15-34 years, while minority (8.0\%) were between 34-49 years (Table 1).

The Male respondents (46\%) and female respondents (58.3\%) had attained primary level of education. However, a few male respondents $(16.1 \%)$ and female respondents $(5.7 \%)$ had obtained the tertiary level of education. It was also noted that $16.1 \%$ of the female respondents and $7.1 \%$ of male respondents had no basic education.

Majority of the respondents (79.6\%) were in a monogamous type of family and both male and women respondents were in agreement.

Table 1:- Demographic characteristic of the respondents

\begin{tabular}{|c|c|c|c|c|c|}
\hline \multirow{2}{*}{\multicolumn{2}{|c|}{ Variable }} & \multicolumn{2}{|c|}{ Male } & \multicolumn{2}{|c|}{ Female } \\
\hline & & $\mathbf{N}$ & $\%$ & $\mathbf{N}$ & $\%$ \\
\hline \multirow[t]{9}{*}{ Age } & $15-19$ & 8 & 3.8 & 9 & 4.3 \\
\hline & $20-24$ & 61 & 28.9 & 88 & 41.7 \\
\hline & $25-29$ & 88 & 41.7 & 76 & 36.0 \\
\hline & $30-34$ & 31 & 14.7 & 21 & 10 \\
\hline & $35-39$ & 13 & 6.2 & 11 & 5.2 \\
\hline & $40-44$ & 7 & 3.3 & 4 & 1.9 \\
\hline & $45-49$ & 3 & 1.4 & 2 & 0.9 \\
\hline & Total & 211 & 100.0 & 211 & 100.0 \\
\hline & {$[\bar{X} \pm S D(R)]$} & \multicolumn{2}{|c|}{$[27.3 \pm 5.83(30)]$} & \multicolumn{2}{|c|}{$[26.0 \pm 4.83(27)]$} \\
\hline \multirow[t]{5}{*}{ Education } & No education & 15 & 7.1 & 34 & 16.1 \\
\hline & Primary & 97 & 46.0 & 123 & 58.3 \\
\hline & Secondary & 65 & 30.8 & 42 & 19.9 \\
\hline & Tertiary & 34 & 16.1 & 12 & 5.7 \\
\hline & Total & 211 & 100.0 & 211 & 100.0 \\
\hline \multirow{2}{*}{\multicolumn{2}{|c|}{ Variable }} & \multicolumn{2}{|c|}{ Male } & \multicolumn{2}{|c|}{ Female } \\
\hline & & $\mathbf{Y}$ & $\mathbf{N}$ & $\mathbf{Y}$ & $\mathbf{N}$ \\
\hline \multirow[t]{2}{*}{ Type of Marriage } & Monogamy & 168 & 79.6 & 165 & 78.2 \\
\hline & Polygamy & 43 & 20.4 & 46 & 21.8 \\
\hline \multirow[t]{6}{*}{ Occupation } & Unemployed & 61 & 28.9 & 112 & 53.1 \\
\hline & Self-employed & 43 & 20.4 & 7 & 3.3 \\
\hline & Casual labour & 52 & 24.6 & 66 & 31.3 \\
\hline & Employed private sector & 26 & 12.3 & 16 & 7.6 \\
\hline & Employed government sector & 29 & 13.7 & 10 & 4.7 \\
\hline & Total & 211 & 100.0 & 211 & 100.0 \\
\hline \multirow[t]{3}{*}{ Religion } & Christian & 173 & 82.0 & 160 & 75.8 \\
\hline & Muslim & 38 & 18.0 & 51 & 24.2 \\
\hline & Total & 211 & 100.0 & 211 & 100.0 \\
\hline \multirow[t]{3}{*}{ Period of marriage } & $\leq 10$ years & 127 & 60.2 & 127 & 60.2 \\
\hline & $>10$ Years & 84 & 39.8 & 84 & 39.8 \\
\hline & Total & 211 & 100 & 211 & 100 \\
\hline \multirow[t]{6}{*}{ Number of children } & 1 & 12 & 5.7 & 12 & 5.7 \\
\hline & $2-4$ & 187 & 88.6 & 187 & 88.6 \\
\hline & $5-7$ & 7 & 3.3 & 7 & 3.3 \\
\hline & Above 7 & 5 & 2.4 & 5 & 2.4 \\
\hline & Total & 211 & 100.0 & 211 & 100.0 \\
\hline & $\bar{X} \pm S D(R)$ & \multicolumn{4}{|c|}{$2.17 \pm 5.0 .708(8)$} \\
\hline
\end{tabular}


In relation to employment, $28.9 \%$ of the male were unemployed while $53.1 \%$ of the female were unemployed. Male respondents who were employed by the Government sector was at $13.7 \%$ compared to $4.7 \%$ of female respondents. Most of the respondents are casual labourers with female respondents leading with $31.3 \%$ compared to $24.6 \%$ of the male respondents. More males $20.4 \%$ were self-employed as compared to $3.3 \%$ of the female respondents who are self-employed. A high proportion $(82.0 \%)$ of the respondents were Christians with majority of them having 2-4 children and $(60.2 \%)$ of the respondents had been in marriage for ten years and below.

In terms of the relationship of the occupation and education, majority of the respondents who were employed were educated as compared to those who were unemployed (Figure 1).

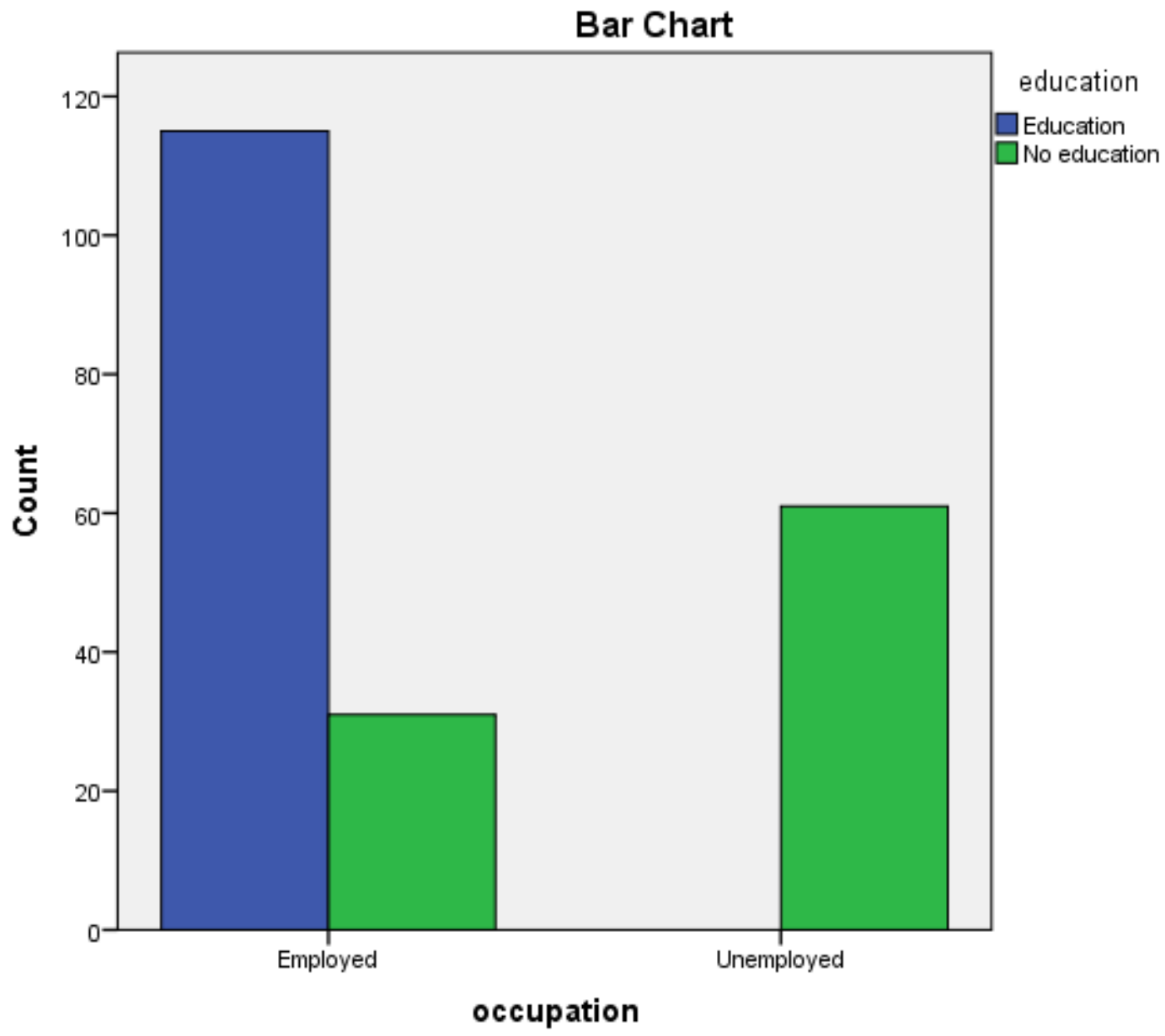

Antenatal Care attendance:-

Figure 1:- Occupation and education of the respondents

The Pregnant women are expected to attend four focused antenatal visits to ensure quality antenatal care. This enables care and early interventions to promote good maternal health and prevent complications during pregnancy, including labour and postnatal. From the analysis of odd ratio, it showed that, type of marriage (OR: 1.3) and living together (OR: 1.9) are more likely to influence the pregnant woman's decision to seek antenatal care service (Table 2)The study also revealed that $79.6 \%$ of those in monogamy type of marriage and $86.7 \%$ who were living together attended ANC (Table 2). 
Table 2: Male partner socio demographic factors and influence on wife attendance for antenatal care

\begin{tabular}{|c|c|c|c|c|c|c|c|}
\hline \multirow{2}{*}{\multicolumn{2}{|c|}{ Variable }} & \multicolumn{2}{|c|}{ wife attended antenatal clinic } & \multirow{3}{*}{$\begin{array}{l}\text { Chi- } \\
\text { square } \\
0.627\end{array}$} & \multirow[t]{2}{*}{ df } & \multirow[t]{2}{*}{ p-value } & \multirow{2}{*}{$\begin{array}{l}\text { Odd } \\
\text { ratio }\end{array}$} \\
\hline & & Yes & No & & & & \\
\hline \multirow[t]{2}{*}{ Age } & $15-34$ & 183 & 5 & & 1 & 0.429 & 0.973 \\
\hline & $35-49$ & 23 & 0 & & & & \\
\hline \multicolumn{2}{|l|}{ Total } & 206 & 5 & & & & \\
\hline \multirow[t]{2}{*}{ Type of marriage } & Monogamy & 168 & 0 & \multirow[t]{3}{*}{20.009} & \multirow[t]{3}{*}{1} & \multirow[t]{3}{*}{0.001} & \multirow[t]{3}{*}{1.132} \\
\hline & Polygamy & 38 & 5 & & & & \\
\hline \multicolumn{2}{|l|}{ Total } & 206 & 5 & & & & \\
\hline \multirow{2}{*}{$\begin{array}{l}\text { Living together } \\
\text { with wife at the time } \\
\text { of her last pregnancy }\end{array}$} & Yes & 183 & 4 & \multirow[t]{3}{*}{0.378} & \multirow[t]{3}{*}{1} & \multirow[t]{3}{*}{0.539} & \multirow[t]{3}{*}{1.989} \\
\hline & No & 23 & 1 & & & & \\
\hline \multicolumn{2}{|l|}{ Total } & 206 & 5 & & & & \\
\hline \multirow[t]{2}{*}{ Education } & Education & 175 & 5 & \multirow[t]{3}{*}{0.882} & \multirow[t]{3}{*}{1} & \multirow[t]{3}{*}{0.348} & \multirow[t]{3}{*}{0.972} \\
\hline & No education & 31 & 0 & & & & \\
\hline \multicolumn{2}{|l|}{ Total } & 206 & 5 & & & & \\
\hline \multirow[t]{2}{*}{ Occupation } & Employed & 145 & 5 & \multirow[t]{3}{*}{2.083} & \multirow[t]{3}{*}{1} & \multirow[t]{3}{*}{0.149} & \multirow[t]{3}{*}{0.967} \\
\hline & Unemployed & 61 & 0 & & & & \\
\hline \multicolumn{2}{|l|}{ Total } & 206 & 5 & & & & \\
\hline
\end{tabular}

Male partners' decision on where the wife attended antenatal clinic:-

On whether socio-demographic factors influenced the male partner to be involved in the decision on where the pregnant woman attended the antenatal clinic. It was found out that the male partners age, education and occupation was a significant factor on male partners being involved in the decision on where the wife attended ANC $(p=0.001)$. However, there is no association in the type of marriage and living together to influence the man to be involved in the decision on where the woman attended the antenatal clinic $(p=0.469 ; 0.154)$. From the analysis of odd ratio, it revealed that, living together $(\mathrm{OR}=2.064)$, education $(\mathrm{OR}=2.030)$ and occupation $(2.103)$ was two times more likely to influence the male partner to be involved in the decision on where the woman attended the antenatal clinic service than age and type of marriage $(\mathrm{OR}=0.480 ; 0.687)$ (Table 3$)$.

Table.3:- Male partners involved in decision on where the pregnant woman attended antenatal clinic

\begin{tabular}{|c|c|c|c|c|c|c|c|}
\hline \multirow{2}{*}{\multicolumn{2}{|c|}{ Variable }} & \multicolumn{2}{|c|}{$\begin{array}{l}\text { Involved in the } \\
\text { decision on where } \\
\text { wife } \\
\text { antenatal care }\end{array}$} & \multirow[t]{2}{*}{ Chi-square } & \multirow[t]{2}{*}{ Df } & \multirow[t]{2}{*}{ P-value } & \multirow[t]{2}{*}{ Odd ratio } \\
\hline & & Yes & No & & & & \\
\hline \multirow[t]{2}{*}{ Age } & $15-34$ & 179 & 9 & \multirow[t]{3}{*}{144.396} & \multirow[t]{3}{*}{1} & \multirow[t]{3}{*}{0.001} & \multirow[t]{3}{*}{0.480} \\
\hline & $35-49$ & 0 & 23 & & & & \\
\hline \multicolumn{2}{|l|}{ Total } & 179 & 32 & & & & \\
\hline \multirow{2}{*}{$\begin{array}{l}\text { Type of } \\
\text { marriage }\end{array}$} & Monogamy & 141 & 27 & \multirow[t]{3}{*}{0.525} & \multirow[t]{3}{*}{1} & \multirow[t]{3}{*}{0.469} & \multirow[t]{3}{*}{0.687} \\
\hline & Polygamy & 38 & 5 & & & & \\
\hline \multicolumn{2}{|l|}{ Total } & 179 & 32 & & & & \\
\hline \multirow{2}{*}{$\begin{array}{l}\text { Living } \\
\text { together with } \\
\text { wife at the } \\
\text { time of her } \\
\text { last } \\
\text { pregnancy }\end{array}$} & Yes & 161 & 26 & \multirow[t]{3}{*}{2.036} & \multirow[t]{3}{*}{1} & \multirow[t]{3}{*}{0.154} & \multirow[t]{3}{*}{2.064} \\
\hline & No & 18 & 6 & & & & \\
\hline \multicolumn{2}{|l|}{ Total } & 179 & 32 & & & & \\
\hline \multirow[t]{2}{*}{ Education } & Education & 165 & 15 & \multirow[t]{3}{*}{44.455} & \multirow[t]{3}{*}{1} & \multirow[t]{3}{*}{0.001} & \multirow[t]{3}{*}{2.030} \\
\hline & No education & 14 & 17 & & & & \\
\hline \multicolumn{2}{|l|}{ Total } & 179 & 32 & & & & \\
\hline \multirow[t]{2}{*}{ Occupation } & Employed & 150 & 0 & 92.756 & 1 & 0.001 & 2.103 \\
\hline & Unemployed & 29 & 32 & & & & \\
\hline \multicolumn{2}{|l|}{ Total } & 179 & 32 & & & & \\
\hline
\end{tabular}

The number of times the husband accompanied wife for ANC 
The majority $(51.18 \%)$ of the respondents did not accompany the woman to antenatal clinic. However, most respondents $(44.08 \%)$ of those who accompanied only accompanied once (Figure 2 ).

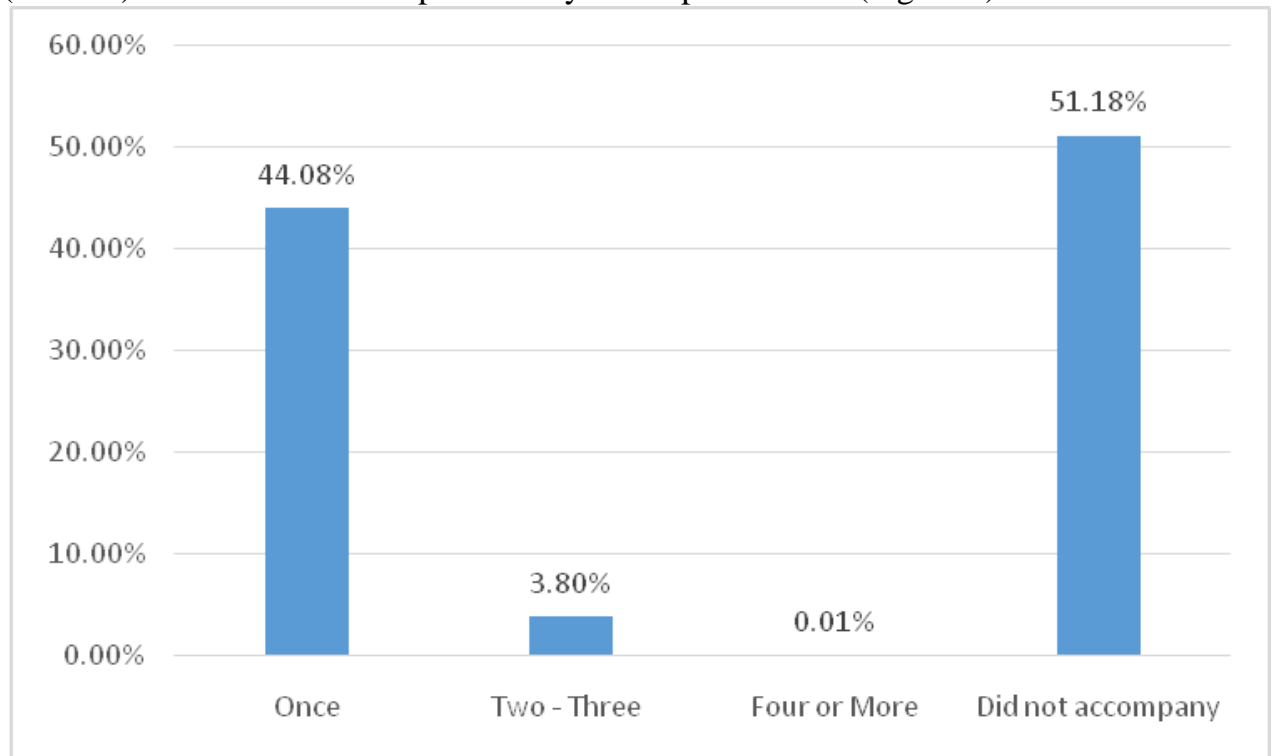

Figure 2:- The number of times the male partner accompanied wife for ANC

Male partner support during pregnancy:-

Majority (69.7\%) of the respondents provide funds for ANC compared to helping with household chores and reminding the woman about her ANC. The study also shows majority of the respondents aged between 15 and 34 provide funds compared to those who are between 35 and 49 (Table 4). The results indicates that majority (62.3\%) of the respondents in monogamous family provide funds compared to those who are in polygamous family. Those with education and are employed provide support compared to those who have no education and are unemployed (Table 4).

Table 4: Male partner Support during pregnancy

\begin{tabular}{|c|c|c|c|c|c|}
\hline \multirow{2}{*}{\multicolumn{2}{|c|}{ Variable }} & \multicolumn{4}{|c|}{$\begin{array}{l}\text { Male partner Support provided to the wife during her last } \\
\text { pregnancy }\end{array}$} \\
\hline & & \multirow{2}{*}{ 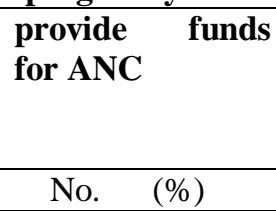 } & \multirow{2}{*}{$\begin{array}{l}\text { Reminded } \\
\text { her of her } \\
\text { ANC } \\
\text { No. }(\%) \\
\end{array}$} & \multirow{2}{*}{$\begin{array}{l}\begin{array}{l}\text { Helped } \\
\text { with } \\
\text { household } \\
\text { chores }\end{array} \\
\text { No. }(\%) \\
\end{array}$} & \multirow{2}{*}{$\begin{array}{l}\text { No support } \\
\text { No. }(\%) \\
\end{array}$} \\
\hline & & & & & \\
\hline \multirow[t]{2}{*}{ Age } & $15-34$ & $141(66.8)$ & 5 & $6(2.8)$ & $50(23.7)$ \\
\hline & $35-49$ & $6(2.8)$ & 0 & 0 & $34(16.1)$ \\
\hline \multicolumn{2}{|l|}{ Total } & 147(69.7) & $5(2.4)$ & $6(2.8)$ & 84(39.8) \\
\hline \multirow[t]{2}{*}{ Type of marriage } & Monogamy & $142(67.3 \%)$ & 5 & $6(2.8)$ & $41(19.4)$ \\
\hline & Polygamy & 5 & 0 & 0 & $43(20.4)$ \\
\hline \multicolumn{2}{|l|}{ Total } & 147(69.7) & $5(2.4)$ & $6(2.8)$ & 84(39.8) \\
\hline \multirow{2}{*}{$\begin{array}{l}\text { living together with } \\
\text { wife }\end{array}$} & Yes & $131(62.1)$ & $5(2.4)$ & $5(2.4)$ & $72(34.1)$ \\
\hline & No & $16(7.6)$ & 0 & 1 & $12(5.7)$ \\
\hline \multicolumn{2}{|l|}{ Total } & $147(69.7)$ & $5(2.4)$ & $6(2.8)$ & 84(39.8) \\
\hline \multirow[t]{2}{*}{ Education } & Education & 119(56.4) & 5 & 6 & $50(23.7)$ \\
\hline & No education & $28(13.3)$ & 0 & 0 & $34(16.1)$ \\
\hline \multicolumn{2}{|l|}{ Total } & 147(69.7) & $5(2.4)$ & $6(2.8)$ & 84(39.8) \\
\hline \multirow[t]{2}{*}{ Occupation } & Employed & $91(42.7)$ & $5(2.4)$ & $6(2,8)$ & $50(23.7)$ \\
\hline & Unemployed & $56(26.5)$ & 0 & 0 & $34(16.1)$ \\
\hline \multicolumn{2}{|l|}{ Total } & $147(69.7)$ & $5(2.4)$ & $6(2.8)$ & 84(39.8) \\
\hline
\end{tabular}

Male partner Support during labour and delivery 
The study results reveals that majority (63\%) of the respondents provide funds for transport compared to helping with household chores and staying with her during labour and delivery. Majority of the respondents (60.2\%) aged between 15 and 34 provide funds for transport compared to those who are between 35 and 49 . The study also indicated that Monogamous type of family provide funds for transport compared to those who are in polygamous family. Those with education and are employed provide support compared to those who have no education and are unemployed (Table 5).

Table 5: Male partner Support during labour and delivery

\begin{tabular}{|c|c|c|c|c|c|}
\hline & \multicolumn{4}{|c|}{ Male partner Support during labour and delivery } \\
\hline \multicolumn{2}{|l|}{ Variable } & \multirow{2}{*}{$\begin{array}{l}\begin{array}{l}\text { provided } \\
\text { funds for } \\
\text { transport }\end{array} \\
\text { NO. }(\%) \\
\end{array}$} & \multirow[t]{2}{*}{$\begin{array}{l}\text { stayed with } \\
\text { her during } \\
\text { labour }\end{array}$} & \multirow[t]{2}{*}{$\begin{array}{l}\text { Helped with } \\
\text { household } \\
\text { chores while } \\
\text { she was away } \\
\text { NO. }(\%) \\
\end{array}$} & \multirow[t]{2}{*}{$\begin{array}{l}\text { No } \\
\text { support } \\
\text { NO. }(\%) \\
\end{array}$} \\
\hline & & & & & \\
\hline \multirow[t]{2}{*}{ Age } & $15-34$ & $127(60.2)$ & 5 & 6 & 50 \\
\hline & $35-49$ & 6 & 0 & 0 & 17 \\
\hline \multicolumn{2}{|l|}{ Total } & $133(63)$ & $5(2.4)$ & $6(2.8)$ & $67(31.8)$ \\
\hline \multirow{2}{*}{$\begin{array}{l}\text { Type of } \\
\text { marriage }\end{array}$} & Monogamy & $128(60.7)$ & 5 & 6 & 29 \\
\hline & Polygamy & 5 & 0 & 0 & 38 \\
\hline \multicolumn{2}{|l|}{ Total } & $133(63)$ & $5(2.4)$ & 6 & 67(31.8) \\
\hline \multirow[t]{2}{*}{ Education } & Education & $119(56.4)$ & 5 & 6 & 17 \\
\hline & No education & 14 & 0 & 0 & 50 \\
\hline \multicolumn{2}{|l|}{ Total } & $133(63)$ & 5(2.4) & 6 & 67(31.8) \\
\hline \multirow{2}{*}{ Occupation } & Employed & 89 & 5 & 6 & 50 \\
\hline & Unemployed & 44 & 0 & 0 & 17 \\
\hline \multicolumn{2}{|l|}{ Total } & $133(63)$ & $5(2.4)$ & 6 & $67(31.8)$ \\
\hline
\end{tabular}

Male partner support during postnatal period

This is the support that male partners offer to their wives after delivery and it revealed that majority (71\%) mainly provide food compared to any other kind of support as seen in table below. The results revealed that majority (71\%) of the respondents provided food during the postnatal period. The results also showed that the respondents aged between 35 and 49 together with those who are unemployed with no education never helped in household chores. Minority (3.3\%) of the male respondents provided funds for the upkeep of the woman (Table 6).

Table 6: Male partner support during postnatal

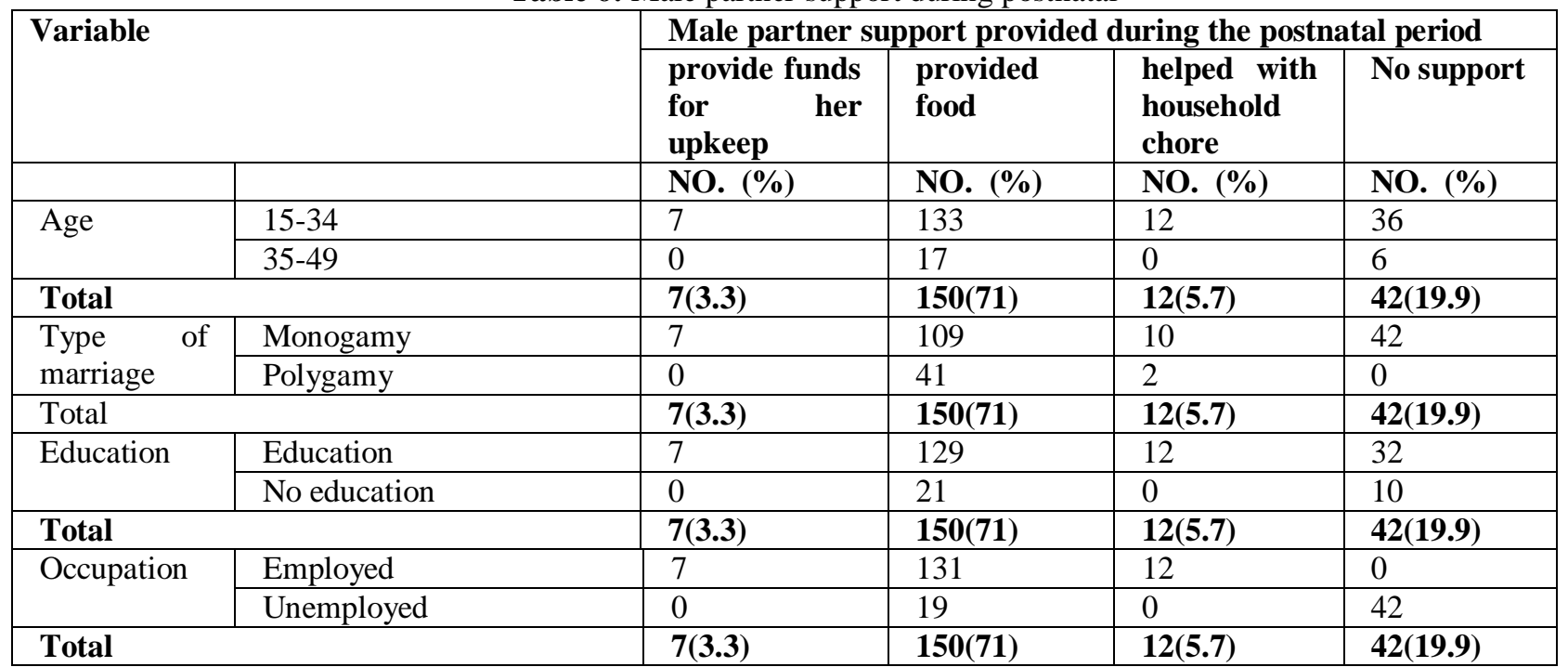

Attitude of health care staff

The health care facility staffs were friendly as indicated by male partner who at least visited the health facility (87.7\%) (Table 7). 
Table 7: Attitude of health facility staff

\begin{tabular}{|c|c|c|c|c|c|}
\hline \multicolumn{2}{|l|}{ Variable } & \multicolumn{4}{|c|}{ Describe the attitude of the health staff } \\
\hline & & \multirow{2}{*}{$\begin{array}{l}\text { Friendly } \\
\text { No. }(\%)\end{array}$} & \multirow{2}{*}{$\begin{array}{l}\text { Unfriendly } \\
\text { No. }(\%)\end{array}$} & \multirow{2}{*}{$\begin{array}{l}\text { Indifferent } \\
\text { No. }(\%)\end{array}$} & \multirow{2}{*}{$\begin{array}{l}\text { Don't know } \\
\text { No. }(\%)\end{array}$} \\
\hline & & & & & \\
\hline \multirow[t]{2}{*}{ Age } & $15-34$ & $181(85.7)$ & 0 & 0 & $21(10)$ \\
\hline & $35-49$ & $4(1.9)$ & $14(6.6)$ & $22(10.2)$ & 0 \\
\hline \multicolumn{2}{|l|}{ Total } & $185(87.7)$ & 14(6.6) & $22(10.2)$ & 21(10) \\
\hline \multirow[t]{2}{*}{ education } & Education & $157(74.4)$ & $2(0.9)$ & 0 & $21(10)$ \\
\hline & No education & $28(13.3)$ & $12(5.7)$ & $22(10.4)$ & 0 \\
\hline \multicolumn{2}{|l|}{ Total } & 185(87.7) & 14(6.6) & 22(10.2) & 21(10) \\
\hline \multirow[t]{2}{*}{ occupation } & Employed & $131(62,1)$ & 0 & 0 & $21(10)$ \\
\hline & Unemployed & $54(25.6)$ & $14(6.6)$ & $22(10.2)$ & 0 \\
\hline \multicolumn{2}{|l|}{ Total } & $185(87.7)$ & $14(6.6)$ & $22(10.2)$ & 21(10) \\
\hline
\end{tabular}

The study revealed $10 \%$ who did not attend the health facility didn't have information on the attitude of staff. It was also noted that majority $(81 \%)$ of the respondents said they spend reasonable time at the health facility while $23.7 \%$ reported to have taken too long time duration.

\section{Discussion:-}

The demographic pattern showed that majority of the respondents $(89.1 \%)$ were found within the age groups of 15 to 34 years; this could be attributed to inclusion criteria of having the youngest child equal or less than one year. This was similar to a study done in Ghana where the majority $(76.5 \%$ ) were from the same age group (Dansowaa, 2013). The results also showed most women get married earlier than men as seen in ages 20-24 (41.7\%). The early marriage of women can be attributed to low level of their education as majority of them had primary education $(58.3 \%)$ or no education $(16.1 \%)$. The low level of education among the women was also portrayed by the rate of unemployment $(58.3 \%)$ compared to that of men $(28.9 \%)$ unemployed. This concurs with study done in Gambia on the price to pay for maternal health care services which showed that majority of the women had low education (Lochting, 2010). The respondents between ages 35- 49 were few, this is because of the inclusion criteria of the sample where the respondents were supposed to have their younger child equal to or less than one year old.

Majority of the respondents were unemployed or employed as casual labourers making it a challenge to support maternal issues. This was also replicated in Tanzania were majority (64.9\%) were unemployed (Danforth et al., 2012) The results showed that $82 \%$ were Christians and since the Christian values does not allow polygamy, it is assumed that the high percentage of monogamy is reflected by the Christian values. It also concurs with the study done in Tanzania and Kenya (Danforth et al., 2012; Onyango et al., 2010). From the analysis majority of the respondents have 2-4 children while minorities have more than five children.

The husband and wife living together will influence pregnant woman's decision to seek antenatal care (ANC). This concurs with a study done on birth preparedness in Uganda (Kakaire et al., 2011). It could also be attributed to the fact that they are staying together hence can remind or escort the wife to the ANC clinic. Another study done in cape town on male involvement in PMTCT revealed that couples who lived together were involved and could escort their wives to the health facility for maternity care (Barron et al., 2013). However, the age of the male partner respondents did not have any influence. This concurs with the study done in eastern Uganda on male partner antenatal attendance who did not find any association between the male's age and Male involvement (Byamugisha et al., 2011). It also agrees with Wassie et al.,(2014) and differs with the study done in Kinshasha Zaire (Ditekeman et al., 2012) who revealed that men with women older than 25 years were involved in maternity care. The husband's role during the antenatal period was explained by gender-specific reasons that household chores were women's job, men only assist when the woman is pregnant and cannot manage to perform. This was well illustrated during both male and female FGD.

"My husband and I live together and he will make sure I have gone to antenatal clinic for checkup, he reminds me that the baby's health is important.... But he (husband) doesn't come with me to the clinic... (A mother of two - FGD)

Educated men that escorted their wives were stereotype and subjected to gossip by their male counterparts and interestingly by women found in the clinics while in the process of seeking pregnancy care. This resulted to 
prejudicial views like, husband's too much love for the wife, the clinic being a domain of women and women should escort women to clinics and not men. This concurs with a study in Ghana during a male FGD (Dansowaa, 2013). Another study in eastern Uganda did not escort their wives to the health facility for fear of HIV testing (Byamugisha, 2011). Large age gap within couples was another factor that restricted men from escorting women to clinics. Old men married the young girls and felt ashamed to visit clinics together with their partners despite the status attached to marrying a young wife.

"The men who dared escort their wives for ANC clinic were seen as weak and that their wives must have cooked something for them in terms of witchcraft therefore this men were ridiculed and sidelined by other real men.... I would not like that to happen to me.... (A male respondent during FGD)

Men were identified with masculine role of providing financial support as narrated during FGD. Similarly, in a study done in Northern Nigerian community on birth preparedness by Iliyasu (2010), it was found that the most universal form of male participation during pregnancy was financial support, nutrition, psychological support and birth preparedness in terms of material support and transport arrangements. This concurs with studies done in New York on male partner antenatal attendance and on couples autonomy and health care in Nepal (Cohen et al., 2000; Allendorf, 2007).

Men's company and physical support of women to seek antenatal and delivery care was merited by most informants but largely restricted by myriad of factors. Some men felt it was their responsibility to escort women to clinics and offer physical support when needed, but this was deterred by men's job responsibility. This agrees with a study done in Gambia that men wished to escort their wives to ANC but were deterred by their responsibility as providers of families and the type of work they do (Lotching et al., 2010). Men were seen and felt as the providers of their families. It was further expressed by men that their absence from work and being present in the clinic together with their partners could have left children without food, as many felt an hour absence from work will mean a struggle for the next day. Most informants reported having limited income and needed more hours of work to meet their survival. This concurs with the study done in Busia, Kenya were majority of the men were casual laboures and motorbike (Boda boda) riders. (Kwambai et al., 2013).

Some of the men saw women to be mature enough to visit the clinic alone or to be escorted by their fellow women but not men. Some men expressed opinions that sick women should be cared by their fellow women and not men for privacy reasons. This concurs with study done in Cameroon by Nkuoh et al., (2013), and in western Kenya (Onyango et al., 2010).This explained how pregnancy and childbirth was viewed as women responsibility and mostly seen as a women issues.

"Where are these men, my husband leaves very early in the morning and comes back at night. He is not even there to see whether he can escort me to antenatal clinic, though he has to go out and work to enable us get what to eat and even get some money for transport to attend ANC clinic." (A mother of two, Housewife during FGD)

Male partners who were educated, had an occupation and living together (OR: 2.030, 2.103, 2.064) were two times more likely to influence the pregnant woman decision on where to seek ANC as compared to those without education, no employment and were not living together. This concurs with a study on birth preparedness and complication readiness done in Nothern Nigeria (Iliyasu, 2010). The men acknowledged during FGD that they could decide where the wife would attend ANC clinic and offer transport but lamented that they had no time to escort their wives for the ANC care. This concurs with the study done in western Kenya (Onyango et al., 2010) and differs from study done by Cohen et al., (2000) in New York. In conclusion male partners can influence pregnant women's decision to seek ANC depending on their socio demographic characteristics.

Male partner's ability to be present during antenatal care visits is subject to numerous external constraints, such as, social cultural factors, time, work demands, and other family members' attitudes toward men's involvement. The data revealed that male partners who discussed maternal health issues with the wives were more likely to discuss with the health care provider. This was seen with significant value on those who discussed maternal health issues which included those aged 15-34 years and were educated. This concurs with Dansowaa, (2013) in Ghana. Male 
partners acknowledged being given the first priority when they accompany their wives for care. This concurred with the study done in Uganda (Kakaire et al., 2011).

"When a woman goes to the antenatal clinic together with her husband she is allowed to go in first than the one who comes alone. Even if a woman comes at 12 noon with her husband and the other one came early in the morning but without a husband, she is told to wait and the woman who came with her husband would be served first. Just because it is the law that the government put in place to promote male involvement in this program but still being ridiculed by colleague men supersedes the first priority that will be given to me and my wife"(Male participant during FGD)

The decision making powers of men were mostly based on religious obligations, cultural and traditional reasons and husbands being main providers and custodian of money for transport fares for women to access antenatal care. However, women's decision to seek delivery care was largely determined by the pregnant women themselves contrary to a study done in Busia Kenya by Nanjala \&Wanjala (2012) and in Gambia where mothers and mothers' in-laws and elderly women in the communities were the key decision makers (Lotching et al., 2010). Essentially, few respondents saw decision making and care seeking as a process that requires communication between couples, but this was restricted by culture and individual disposition, which seemingly rendered men's limited understanding of reproductive needs of women. This concurs with the study done by Onyango et al., (2010) in western Kenya and in Uganda (Kakaire et al., 2011).

Some informants felt ashamed to talk to their partners about pregnancy and child birth issues and this further spurred women's perceived difficulties in informing their husbands about their proposed visit to seek antenatal care. A few others felt they were just ashamed to talk to a man about reproductive issues. This concurs with the study done in Malawi were women feared to discuss their reproductive health issues with men (Kululanga et al., 2011). Lack of communication often resulted to men being oblivious of women's health care seeking intentions as few men also kept to themselves waiting for the woman to make a request. From the study spouses living together were 1.7 times more likely to discuss maternal health issues with the partner (OR 1.706). This differs from a study done in Nigeria indicating that, those educated were more likely to discuss reproductive health issues with the wife (Banalola et al., 2009)

“When my wife is pregnant.... She never tells me... I only know by observing her stomach....A tree flowers before bearing fruits (literally look for signs of pregnancy)...most women do hide pregnancy issues from their husbands... and you know one can offer help on something one knows about...that's why we (men) keep to ourselves too"' (A 28 years husband narrated during FGD)

Some women expressed similar feelings suggesting some social cultural factors influence, which to some extent further influenced individual dispositions regarding husband - wife reproductive health communication and care seeking attention.

"I never discuss pregnancy and child birth issues with my husband...I do feel ashamed...In our culture it is very hard for a man and woman to discuss pregnancy and child birth which is a good morale" (A 32 year old woman during FGD).

Kululanga (2011) found that male who were involved in discussing reproductive health issues with the wives lead to favorable outcomes for the entire family and increases the likelihood that the father will continue to provide care throughout Pregnancy and after birth. Additionally, Anderson et al., (2011) argued that men can participate in helping pregnant women stay health by making sure that the women get proper antenatal care which may entail providing transportation or funds to pay for her visits. This included accompanying the wife during antenatal visits where the man can learn about the symptoms of pregnancy complications and how to respond to an obstetric emergency. 
The study revealed that respondents had the belief that antenatal clinics were women's places and men should not interfere. This finding is in agreement with Byamugisha (2010), who reiterates that men frequently perceive ANC services were designed and reserved for women, thus men are embarrassed to find themselves in such "female" places. Some men believe it was not good to follow your wife to the antenatal clinic and therefore ANC is "a woman's responsibility". This contradicts with the study done in Cameroon were Men saw the benefits of PMTCT as they accompanied their wives (Nkuoh et al., 2010). The identification of men with masculine roles affirm the notion that men are socialized to be superior in terms of decision making and to be financial providers. As such it has proved to be a challenge for male partners to participate in activities that are feminine including health issues concerning their wives. This agrees with a study done in Kinshasha Zaire (Wassie et al., 2012), and one of the participants made an exclamation;

"Heheeee!!! (exclamation made) "MwanaumeMwanga" (A Wanga man) cannot dare wash utensils or do household chores. He can't, he is a man and therefore household chores are meant for women. Even his own mother can't allow him do that..... (A mother of one, primary school teacher)"

At the same time, although some have desired to support their partners, they have been curtailed by cultural definitions of maleness and roles of masculinity. As a result, they fear being excluded and ridiculed by other men in the community whom they imagine will call their manhood into question. Similarly, in a study done in western Kenya, Onyango et al., (2012) observed that gender norms were one of the factors that inhibit male involvement in maternal health care. For instance, men are not expected culturally to accompany their wives to the clinic. If they do, this was perceived by their peers as a demonstration of weakness. This agrees with the studydone in Malawi were men who accompanied their wives were referred as weak (Aarnio et al., 2009)

Male partners during FGD indicated that distance and time spent attending ANC with wife would result to time wasted for work to earn since most of them were either casual labourers are "Bodaboda" riders. A previous qualitative study conducted in western Kenya by Reece et al., (2010) found that the distance that the male partners have to travel to the clinics to participate in the education, blood tests and counseling, the costs of the transport to the clinics and the amount of time per appointment at the clinic were identified as barriers to male involvement. This could also be contributed by the fact that majority of the male partners are casual laboures. It also concurs with study done in Kenya on skilled deliveries (Nanjala and Wamalwa, 2012). Access or logistical challenges on the part of men prevented them from participating in ANC. Men talked about their perceived principal responsibilities as providers. It was also noted in another study that time spent at clinics and away from work or other income generating activities was clearly perceived as a barrier to their participation in ANC program. The distance, the cost of transport and the clinic operation hours were also mentioned with some frequency (Reece et al., 2010).

I have not escorted my wife to any of her ANC during pregnancy because I care

And I have to provide for their food and everything they need for survival.....

(Male Respondent during FGD)

Majority of the respondents appreciated the fact that the clinic was quite heavy and that the health care providers tried a great deal to remain friendly and helpful despite the burn out. This contradicts the study done in Uganda were client felt staff were harsh and not friendly (Kakaire et al., 2011). The findings established that there was dominance of the female staff in the clinic which should be improved if it is to encourage the men to go to the antenatal clinics. This agrees with a study done in Nigeria and Nepal (Mundil, 2013; Mullany et al., 2009). The main complaint was the congestion in the clinic which made men felt out of place and the long queues which wasted so much time in the clinic. The above finding differs with the previous studies where Byamugisha et al., (2010), reported that harsh, critical language directed at Ugandan women from skilled health professionals was a barrier to male participation.

Furthermore, in relation to support during labour and delivery, health care providers did not allow men access. Men mentioned health-care workers not allowing men to enter the delivery room with their partners". This was affirmed by one of the male respondents who mentioned that;

"When I took my wife to hospital for delivery, I was told by sister (nurse midwife), that I have done my part therefore, I should not be seen around. I was told I could only come the next day to check if she had delivered and take her home. So whom am I to disobey the doctor's orders? (A father of one, primary school teacher)" 
"I have had my three children and my husband has never escorted me to antenatal clinic. To me those are women's issues and we discuss it with other women (housewife, a mother of three children)"

There were assumptions and beliefs that husbands' presence during labour was mostly restricted by cultural and traditional beliefs, such as the belief that men became sick and swollen when witnessing their spouse deliver. This agrees with a study done in Tanzania, and Ghana (Danforth et al., 2009; Dansowaa, 2013) They also believed that men became impotent when they see delivery, blood and men losing the potential spiritual powers of their amulets (jujus) if witnessed their spouse deliver. Some of these beliefs ran through different ethnicities and some were specific to certain ethnicity. Nanjala and Wamalwa, (2012) concurs that cultural beliefs in western Kenya had a negative impact on male support for skilled deliveries and timely referrals. Some cultures even restricted physical contact of men and the newly born baby in the first three and four days of postpartum. Finally, Male partners during FGD reiterated that there were actually no taboos or cultural beliefs that really restricted the male partners in participating in maternity care. It contradicts a study done on in Borkina Faso and sub Saharan Africa were taboos existed and interfered with male involvement in reproductive health issues (some, 2014; Ditekemena et al., 2012) However, majority only believed and followed what was said by their seniors without question.

\section{Cconclusions:-}

Majority of the respondents were young adults aged 26-32 years, married and living with their spouses. School education was universal with most of the respondents having secondary school and about half of the respondents unemployed. The unemployment nature may have made the male partner not to involve himself in maternity care services during perinatal period. It was noted that male partners influenced the pregnant women's decision to seek ANC. In regard to participation by discussing maternal health issues and support, their involvement in the health care of their wives was low since very low percentage escorted their wives to the health facility. This still shows that men lag behind in their responsibilities in improving maternal health. Enlightenment programs should therefore be carried out by governmental agencies, non-governmental organizations and other voluntary groups and religious bodies. This may address the involvement of male partners in promoting maternal health care and also being agents of change in improving the quality of life of women as it relates to maternal health thereby bringing about healthy families and indeed healthy nation.

\section{References:-}

1. Aarnio, P., Olsson, P., Chimbiri, A., Kulmala T. (2009) Male involvement in antenatal HIV counseling and testing: exploring men's perceptions in rural Malawi. AIDS Care: Psychological and Socio-medical Aspects of AIDS/HIV, 21:1537-1546.

2. Allendor F., K. (2007). Couples' reports of women's autonomy and health-care use in Nepal. Stud FamPlann, 38:35-46.

3. Anderson, N., Omer, K., Caldwel, D, et al. (2011) Male responsibility and Maternal Morbidity: A cross sectional study in two Nigerian states. BMC health service; 11(suppl 2) 1-11

4. Babalola, S., \& Adesegun, F. (2009). Determinants of use of maternal health services in Nigeria lookingbeyond individual and household factors. BMC Pregnancy and Childbirth, 9 (43), 2393-2943.

5. Backstrom, C., \& Wahn, E., (2009). Support during labour: first time father's descriptions of requested and received support during the birth of their child. Midwifery, 27: 67-73

6. „Byamugisha, R., AAstrom, A., Ndeezi, G., Karamagi, C., Tylleskär, T., Tumwine, J.(2011). Male partner antenatal attendance and HIV testing in eastern Uganda: a randomized facility-based intervention trial. Journal of the InternationalAIDS Society, 14(1), 43.

7. Cohen, S.I., \& Burger,M. (2000). Partnering: A New Approach to Sexual and Reproductive Health. Technical Paper No. 3. New York, NY, USA: United Nations Population Fund. Curr Opin Obstet Gynecol, 22(6):525529.

8. Danforth, E.J., Kruk, M.E., Rockers, P.C., Mbaruku, G., \& Gale,a S. (2009). Household Decision -Making about Delivery in Health Facilities: Evidence from Tanzania. Journal of Health Population Nutrition, 27(5):696-703.

9. Dansowaa DOE R., (2013) Male partner involvement in maternity care in Ablekumasouth district, Accra, Ghana.University of Ghanahttp://ugspace.ug.edu.gh

10. Wamalwa, D (2012).Determinants of male partner involvement in promoting deliveries by skilled birth attendant in Busia, Kenya. Global Journal Of Health Science. Vol.4:2 
11. D'Alieso, L., Vellone, E., Amato, E, et al., (2009). The Positive effects of fathers' attendance to labour and delivery; a quasi-experimental stud. Int. Nursperspect 9; 5-10

12. Iliyasu, Z., Abubakar, I.S., Galadanci, H.S., Aliyu, M.H. (2010). Birth Preparedness, Complication Readiness and Fathers' Participation in Maternity Care in a Northern Nigerian Community. African Journal of Reproductive Health, 14:21-32.

13. Ditekemena,J., Koole,O., Engmann,C., Matendo, R., Tshefu,A., Ryder,R., \&t Colebunders, R. (2012): Determinants of male involvement in maternal and child health services in sub-Saharan Africa: a review. Reproductive Health, 9:32

14. Kakaire,O., Kaye, D. K., \&Osinde, M. O., (2011). Male involvement in Birth preparedness and complication readiness for emergency obstetric referrals in rural Uganda. Reproductive Health, 8(12).

15. Kenya National Bureau of Statistics (KNBS) [Kenya], and ICF International (2010). Kenya Demographic and Health Survey 2008 - 2009. Calverton, MD, USA: KNBS and ICF International

16.

17. Kululanga, L.I., Sundby, J., Malata, A., Chirwa, E. (2011). Striving to promote male involvement in maternal health care in rural and urban settings in Malawi - a qualitative study. Reprod Heal, 8:36.

18. Kulunya L. I., J. Sundby, E. Chirwa, A. Malata, and A. Malura (2012). Barriers to Husbands' Involvement in maternal health care in a Rural setting in Malawi: A qualitative study. Journal of Research in Nursing and Midwifery 1(1): 1-10

19. Lochting L.I. (2010). The Price to Pay for Maternal Health care in Rural Gambia Master's Thesis, Institute of General Practice and Community Medicine,Section for International Health, University of Oslo.

20. Morshan-Bello I O, Adedokum B O, Ojengbede O A, Olayemi O, Oladokun A, Fabamuo O A., (2009). Assessment of the Effect of Psychosocial Support during Childbirth in Ibadan, SouthWest Nigeria: A Randomised Controlled Trial. Australian and New Zealand Journal of Obstetrics and Gynecology, 49: 145150 .

21. Mugenda O.M and Mugenda A.G., (2003). Research Methods: Quantitative and Quantitative Approaches, Africa Centre for Technology Studies, Nairobi.

22. Mullany, B. C., B. Lakhey, D. Shrestha, S. Becker, and M. J. Hindin, (2009) Impact of Husbandse Participation in Antenatal Health Education Services on Maternal Health knowledge. J Nepal Med Assoc;48(173):28-34.MundiI.,(2013). Nigeria demographics profile. Available from:http://www.indexmundi.com/nigeria/birth_rate.html. [Last updated on 2013 Feb 21, Last cited on 2013 Mar 20].

23. Nanjala, M., \&Wamalwa, D., (2012). Determinants of Male Partner Involvement in Promoting Deliveries by Skilled Attendants in Busia, Kenya. Global Journal of Health Science, 4(2), p60 - 67.

24. Nkuoh, G. N., Meyer, D. J., Tih, P. M., \&Nkfusai, J., (2010). Barriers to Men's Participation in Antenatal and Prevention of Mother-to-Child HIV Transmission Care in Cameroon, Africa. Journal of Midwifery \& Women's Health, 55(4),363-369.

25. Onyango, M., Owoko, S., Oguttu, M. (2010). Factors that influencemale involvement in sexual and reproductive healthin Western Kenya: A Qualitative study. African Journal of Reproductive Health; 14(4):3343.

26. Plantin, L., Olukoya, A.A., Ny P. (2011) Positive health outcomes of fathers involvement in pregnancy and childbirth paternal support. A scope study literature review. Fathering; 9: 87 -102

27. Reece, M., Hollub A., Nangami M. \& Lane, K. (2010): Assessing male spousal engagement with prevention of mother-to-child transmission (PMTCT) programs in western Kenya. AIDS Care, 22(6):743-750.

28. Some, D.T., Sombie, I. \&Meda, N. (2013): How decision for seeking maternal care is made-a qualitative study in two rural medical districts of Burkina Faso: Reprod. Health journ, 10:8

29. Kwambai, T.,K. et al., (2013). Perspectives of men on antenatal and delivery care service utilization in rural western Kenya. BMC Pregnancy and childbirth. 13:134

30. Tweheyo, R., Konde-Lu le, J., Tumwesigye, N. M., Sekandi, J. N. (2010). Male partner attendance of skilled antenatal care in peri-urban Gulu district, Northern Uganda. BMC Pregnancy and Childbirth, 10(1), 53.

31. Wassie, L., Bekele A., Ismael A., Tariku N., Heran A., Getnet M., Mitike M., Adamu A., Seifu H. (2014): Magnitude and factors that affect males' involvement in deciding partners' place of delivery in Tiyo District of Oromia Region, Ethiopia. Ethiop. J. Health Dev. 2014; (Special Issue 1) 